\title{
Evaluation of the Chemical Composition of Dry Feeds for Dogs and Cats
}

\author{
Silvânio S. L. Costa, ${ }^{a, b}$ Ana C. L. Pereira, ${ }^{b}$ Elisangela A. Passos, ${ }^{b}$ José P. H. Alves, $^{b}$ \\ Carlos A. B. Garcia ${ }^{b, c}$ and Rennan G. O. Araujo ${ }^{*, a, c}$
}

\author{
${ }^{a}$ Grupo de Pesquisa para Estudos em Química Analítica e Ambiental (GPEQA2), \\ Departamento de Química Analítica, Instituto de Química, \\ Universidade Federal da Bahia (UFBA), 40170-115 Salvador-BA, Brazil \\ ${ }^{b}$ Laboratório de Química Analítica Ambiental (LQA), \\ Universidade Federal de Sergipe (UFS), 49100-000 São Cristóvão-SE, Brazil \\ 'Instituto Nacional de Ciência e Tecnologia (INCT) de Energia e Ambiente, \\ Universidade Federal da Bahia (UFBA), 40170-115 Salvador-BA, Brazil
}

\begin{abstract}
Cat and dog feed production has increased worldwide, and much emphasis has been placed on the importance of determining the mineral composition of pet foods. In this work, the concentrations of $\mathrm{Al}, \mathrm{Ba}, \mathrm{Ca}, \mathrm{Cd}, \mathrm{Cr}, \mathrm{Cu}, \mathrm{Fe}, \mathrm{K}, \mathrm{Mg}, \mathrm{Mn}, \mathrm{Ni}, \mathrm{P}, \mathrm{Sr}, \mathrm{V}$ and $\mathrm{Zn}$ in dry feed for cats and dogs employing inductively coupled plasma-optical emission spectrometry (ICP OES) were determined and evaluated according to regulatory agencies. Forty-one dry feed samples ( 24 dog feed and 17 cat feed) were analyzed. The obtained concentrations ranged from $2.3 \mathrm{mg} \mathrm{kg}^{-1}$ (Ba) to $2.8 \mathrm{~g} \mathrm{~kg}^{-1}$ (Ca) in cat feeds, and from $3.8 \mathrm{mg} \mathrm{kg}^{-1}(\mathrm{Cu})$ to $3.4 \mathrm{~g} \mathrm{~kg}^{-1}(\mathrm{Ca})$ in dog feeds. The concentrations of $\mathrm{P}$ are in accordance with the Brazilian legislation, and $\mathrm{Mn}$ and $\mathrm{Zn}$ contents met the American legislation. The concentration values of $\mathrm{Cu}, \mathrm{K}$ and $\mathrm{Mg}$ presented in some samples were below the limits established by American regulatory agency. Based on multivariate data analysis evaluated from flavors of the products and brands, it was concluded that the feed samples were uniform since there was no trend to group formation and classification according to their mineral composition, except one dog feed brand, which had a significant content of $\mathrm{Al}$ and $\mathrm{Cu}$.
\end{abstract}

Keywords: cat and dog feeds, chemometrics, food safety, mineral composition, ICP OES

\section{Introduction}

The global feed industry for dogs and cats has grown extensively, particularly in Brazil, which occupies the second place in cat and dog feed production behind the United States..$^{1-3}$ Various types of feed are available in the market, and they can be differentiated according to the ingredients, size and breed of the animal, and for animals predisposed to a specific disease..$^{2-4}$

Dry feeds should present a final humidity between 10 and $12 \%$ and be formulated to achieve a specific amount of nutrients, using as raw material cereal grains and products derived from animal sources. Nutrients in premium feed are to benefit the body, mostly by increasing the intestinal health of the animals. ${ }^{2,3,6}$

For this reason, several articles have been published on the nutritional importance and composition of dog and

*e-mail: rgoa01@terra.com.br; rennan@ufba.br cat feeds..$^{1-4,6-13}$ A nutritional evaluation of dry feed for dogs determined the nutritional value of feeds comprising adult dog diets. ${ }^{1}$ Another study evaluated the sources of protein and carbohydrates, considering the digestibility and metabolizable energy of the ingredients used in dog and cat feeds. ${ }^{7}$ Additional zinc sources for adult cats should be considered. ${ }^{10}$

Another study evaluated the conventional and alternative ingredients in the diets of dogs and cats and proposed that the best ingredient is defined by food purpose or product. ${ }^{4}$ Roch $a^{11}$ described the role of biotechnology in optimizing the nutritional requirements of dogs and cats to contribute to the health of the animals. Factors were proposed that could be evaluated in selecting commercial feeds. ${ }^{6}$ The origin of nutrients that comprise dog and cat feed regarding food quality and safety regulations was described. ${ }^{13}$

$\mathrm{Cu}, \mathrm{Cd}, \mathrm{Cr}, \mathrm{Fe}, \mathrm{Ni}, \mathrm{Mn}$ and $\mathrm{Pb}$ contents in feeds for dogs and cats were determined in a study, and it was highlighted the need of attention regarding pet food safety. ${ }^{9}$ In another 
study it was evaluated the effect of addition of zeolites and Yucca schidigera in diets for cats and their effects on mineral excretion, through examination of daily fecal production and the percentage of water in the stool. ${ }^{12}$ The chemical composition in dry food for dogs was evaluated and 16 elements were determined. ${ }^{3}$ An analytical method by inductively coupled plasma with optical emission spectrometry (ICP OES) was optimized to determine the constituents of dry dog and cat feed. ${ }^{2}$

Recently, the determination of $\mathrm{Zn}$ in dry feeds samples, acquired in Brazilian commercial establishments, was performed by energy dispersive X-ray fluorescence spectrometry (EDXRF). ${ }^{14}$ In addition, an EDXRF method was optimized for determination of macro and micro elements in dry feeds collected from European market. ${ }^{15}$

In recent years, multivariate data analysis, such as principal component analysis (PCA) and hierarchical cluster analysis (HCA), have been used to evaluate and characterize the mineral composition of foods, such as fruit juices,${ }^{16}$ okra,,${ }^{17}$ broccoli,${ }^{18}$ cabbage, ${ }^{19}$ wheat flour,${ }^{20}$ kale,${ }^{21}$ and fruits and vegetables. ${ }^{22}$

This study evaluated the inorganic constituent contents (Al, Ba, Ca, Cd, Cr, Cu, Fe, K, Mg, Mn, Ni, P, S, Sr, V and $\mathrm{Zn}$ ) of various flavored dog and cat feeds, offered by brands, using PCA and HCA for multivariate data analysis.

\section{Experimental}

Reagents and standard solutions

All reagents were of analytical grade. The solutions were prepared using deionized water obtained from a reverse osmosis equipment (Gehaka OS 20 LX, São Carlos, Brazil) to a conductivity below $0.18 \mathrm{mS} \mathrm{cm}^{-1}$. Nitric acid at a concentration of $14.0 \mathrm{~mol} \mathrm{~L}^{-1}$ and $30 \% \mathrm{v} \mathrm{v}^{-1}$ hydrogen peroxide were used for sample preparation (Merck, Darmstadt, Germany).

External calibration curves, between 0.1 and $2.0 \mathrm{mg} \mathrm{L}^{-1}$ for $\mathrm{Ba}, \mathrm{Cd}, \mathrm{Cr}, \mathrm{Cu}, \mathrm{Fe}, \mathrm{Mn}, \mathrm{Ni}, \mathrm{Sr}, \mathrm{V}$ and $\mathrm{Zn}$, and between 5 and $200 \mathrm{mg} \mathrm{L}^{-1}$ for $\mathrm{Al}, \mathrm{Ca}, \mathrm{Fe}, \mathrm{K}, \mathrm{Mg}, \mathrm{P}$, and $\mathrm{S}$, were prepared by suitable dilution of stock solutions containing $100 \mathrm{mg} \mathrm{L}^{-1}$ of $\mathrm{Ba}, \mathrm{Cd}, \mathrm{Cr}, \mathrm{Cu}, \mathrm{Fe}, \mathrm{Mn}, \mathrm{Ni}, \mathrm{Sr}, \mathrm{V}$ and $\mathrm{Zn}$ (multielement solution, Titrisol, Merck) and $1000 \mathrm{mg} \mathrm{L}^{-1}$ of $\mathrm{Al}, \mathrm{Ca}, \mathrm{Fe}, \mathrm{K}, \mathrm{Mg}, \mathrm{P}$ and $\mathrm{S}$ (multielement solution, Titrisol, Merck), respectively. For Al determination, the external calibration curve was between 0.1 and $200 \mathrm{mg} \mathrm{L}^{-1}$.

\section{Sampling and sample preparation dry feed}

Forty-one dry feed samples (24 feed samples for dogs and 17 feed samples for cats) were acquired from supermarkets located in Sergipe State, Brazil. The samples were subsequently divided into $50 \mathrm{~g}$ portions, ground to ensure homogeneity and stored in polyethylene containers protected from light.

About $0.25 \mathrm{~g}$ (dry mass) of each sample were placed into a polytetrafluoroethylene (PTFE) container suitable for microwave-assisted digestion. Then, $\mathrm{HNO}_{3}(1.4 \mathrm{~mL}$, $\left.14.0 \mathrm{~mol} \mathrm{~L}^{-1}\right)$ and $\mathrm{H}_{2} \mathrm{O}_{2}\left(2.0 \mathrm{~mL}, 30 \% \mathrm{v} \mathrm{v}^{-1}\right)$ were added. The mixture was kept standing for $30 \mathrm{~min}$, and then $6.6 \mathrm{~mL}$ of deionized water were added. After that, microwaveassisted digestion was performed using a 2-stage heating program. In the first stage, the temperature was increased linearly up to $180{ }^{\circ} \mathrm{C}$, over $5 \mathrm{~min}$ at a maximum power of $400 \mathrm{~W}$, and maintained for $15 \mathrm{~min}$. In the second stage, the temperature was maintained at $180^{\circ} \mathrm{C}$, and the power was increased to $800 \mathrm{~W}$ over $5 \mathrm{~min}$, with the final conditions kept for 5 min more. Then, the samples were transferred to polyethylene tubes, and the volumes were made up to $15 \mathrm{~mL}$ with ultrapure water. The procedure was performed in triplicate. To evaluate the quality of the reagents and the accuracy of the analytical method, blank solutions were prepared, and certified reference materials were digested using the same procedure applied to the feed samples. ${ }^{2}$

Instrumentation

The samples were decomposed using microwaveassisted acid digestion (Mars XPress microwave oven, CEM Corporation, Matthews, USA) equipped with PTFE bottles and temperature and pressure sensors placed inside the reaction vessel. The samples were analyzed by ICP OES with axial configuration (model 720-ES, Vista Pro, Varian, Mulgrave, Australia). For the analyses of the samples a radiofrequency power of $1.2 \mathrm{~kW}$ and nebulizer gas flow rate of $0.8 \mathrm{~L} \mathrm{~min}^{-1}$ were used. Argon gas with minimum of 99.9999\% (White Martins, São Paulo, Brazil)² was used to generate the plasma. The atomic (I) and ionic emission (II) lines least affected by spectral interferences and with a high analytical signal to background ratios were selected. The operating conditions are shown in Table 1.

\section{Results and Discussion}

\section{Quality control}

The analytical method used in this work was previously optimized and validated as described by da Costa $e t$ al. ${ }^{2}$ Limit of quantification (LOQ) values obtained by ICP OES were $7.0 \mathrm{mg} \mathrm{kg}^{-1}$ for $\mathrm{Al}, 0.08 \mathrm{mg} \mathrm{kg}^{-1}$ for Ba, $87 \mathrm{mg} \mathrm{kg}^{-1}$ for $\mathrm{Ca}, 0.12 \mathrm{mg} \mathrm{kg}^{-1}$ for $\mathrm{Cd}, 0.1 \mathrm{mg} \mathrm{kg}^{-1}$ for $\mathrm{Cr}, 0.27 \mathrm{mg} \mathrm{kg}^{-1}$ for $\mathrm{Cu}, 2.7 \mathrm{mg} \mathrm{kg}^{-1}$ for $\mathrm{K}, 1.8 \mathrm{mg} \mathrm{kg}^{-1}$ for $\mathrm{Mg}, 0.3 \mathrm{mg} \mathrm{kg}^{-1}$ for 
Table 1. Characteristics and operating conditions used for analysis by ICP OES with axial configuration

\begin{tabular}{|c|c|c|}
\hline Parameter & \multicolumn{2}{|c|}{ Characteristic } \\
\hline Radiofrequency power / kW & \multicolumn{2}{|c|}{1.20} \\
\hline Plasma gas flow rate / $\left(\mathrm{L} \mathrm{min}^{-1}\right)$ & \multicolumn{2}{|c|}{15.0} \\
\hline Auxiliary gas flow / $\left(\mathrm{L} \mathrm{min}{ }^{-1}\right)$ & \multicolumn{2}{|c|}{1.5} \\
\hline Nebulizer gas flow rate $/\left(\mathrm{L} \mathrm{min}^{-1}\right)$ & \multicolumn{2}{|c|}{0.8} \\
\hline Nebulizer type & \multicolumn{2}{|c|}{ concentric, sea spray } \\
\hline Spray chamber & \multicolumn{2}{|c|}{ cyclone type } \\
\hline No. of replicates & \multicolumn{2}{|c|}{3} \\
\hline Injector tube diameter / $\mathrm{mm}$ & \multicolumn{2}{|c|}{2.4} \\
\hline Signal integration time / s & \multicolumn{2}{|c|}{1.0} \\
\hline \multirow[t]{8}{*}{ Wavelength / nm } & Al I (309.271) & Ba II (233.527) \\
\hline & Ca I (373.690) & Cd II (226.502) \\
\hline & $\mathrm{Cu}$ I (327.395) & Cr II (267.716) \\
\hline & Fe II (238.204) & K I (766.491) \\
\hline & Mg II (285.213) & Mn II (260.569) \\
\hline & Ni II (231.604) & P I (177.434) \\
\hline & S I (181.972) & Sr II (407.771) \\
\hline & V I (311.837) & Zn I (213.857) \\
\hline
\end{tabular}

I: atomic line; II: ionic line.

$\mathrm{Mn}, 0.56 \mathrm{mg} \mathrm{kg}^{-1}$ for Ni, $31 \mathrm{mg} \mathrm{kg}^{-1}$ for $\mathrm{P}, 18 \mathrm{mg} \mathrm{kg}^{-1}$ for $\mathrm{S}, 0.09 \mathrm{mg} \mathrm{kg}^{-1}$ for $\mathrm{Sr}, 0.21 \mathrm{mg} \mathrm{kg}^{-1}$ for $\mathrm{V}$ and $2.0 \mathrm{mg} \mathrm{kg}^{-1}$ for $\mathrm{Zn}$. Values obtained for LOQs were suitable for the range of concentrations of all trace elements evaluated in dry feed samples for cats and dogs.

Accuracy and precision of the analytical method were evaluated through analysis of certified reference materials (CRM) acquired from the National Institute of Standards and Technology (NIST, Gaithersburg, USA): wheat flour (NIST 1567a), bovine liver (NIST 1577), oyster tissue (NIST 1547), and fish protein (DORM-3) from the National Research Council Canada (NRCC, Ottawa, Canada). The concentration values obtained were in agreement with certified values, confirming a good accuracy. The agreement values were: $\mathrm{Al}(98 \pm 4-110 \pm 6 \%), \mathrm{Ba}(86 \pm 2 \%), \mathrm{Ca}(84 \pm 14-100 \pm 4 \%)$, $\mathrm{Cr}(80 \pm 4 \%), \mathrm{Cu}(98 \pm 2-103 \pm 4 \%), \mathrm{Fe}(84 \pm 1-100 \pm 1 \%)$, $\mathrm{K}(94 \pm 5-96 \pm 4 \%), \operatorname{Mg}(86 \pm 2-101 \pm 1 \%), \operatorname{Mn}(86 \pm 2-01 \pm 2 \%)$, $\mathrm{P}(94 \pm 4-103 \pm 4 \%), \mathrm{S}(84 \pm 4-102 \pm 2 \%), \mathrm{Sr}(90 \pm 8-97 \pm 2 \%)$ and $\mathrm{Zn}(95 \pm 6-105 \pm 1 \%)$. Precision was expressed as relative standard deviation (\%RSD), being better than 5.0\% $(n=3)$, confirming the reliability of the analytical procedure.

The analytical method applied in this work presented good accuracy and precision, as confirmed by the results obtained for the standard reference materials (SRMs) and, since the LOQ values are below the minimum allowable concentration established by the Brazilian Ministry of Agriculture, Livestock and Food Supply (Ministério da
Agricultura, Pecuária e Abastecimento, MAPA) ${ }^{5}$ and the Association of American Feed Control Officials (AAFCO) ${ }^{23}$ it can be applied to the determination of the elements in samples of dry feed for cats and dogs.

Determination of mineral content and humidity in feeds for dogs and cats

Sixteen elements, $\mathrm{Al}, \mathrm{Ba}, \mathrm{Ca}, \mathrm{Cd}, \mathrm{Cr}, \mathrm{Cu}, \mathrm{Fe}, \mathrm{K}, \mathrm{Mg}$, $\mathrm{Mn}, \mathrm{Ni}, \mathrm{P}, \mathrm{S}, \mathrm{Sr}, \mathrm{V}$ and $\mathrm{Zn}$ in 41 feed samples (24 for dogs and 17 for cats) were evaluated. $\mathrm{Ca}, \mathrm{Mg}, \mathrm{K}, \mathrm{P}$ and $\mathrm{S}$ were the elements presenting higher concentrations. In all feed samples the concentrations of $\mathrm{Cd}\left(<0.12 \mathrm{mg} \mathrm{kg}^{-1}\right)$ were also determined, but the obtained values were below the LOQ of the analytical method. The average levels and the concentration ranges are presented in Table 2, for cat and dog feeds, respectively. A full assessment is listed in Supplementary Information (SI) section Tables S1 and S2 for cat and dog feeds, respectively.

In this work, the concentrations found in dry feed samples for cats were compared with the established minimum allowable concentration of $\mathrm{Ca}\left(6.0 \mathrm{~g} \mathrm{~kg}^{-1}\right)$, $\mathrm{Cu}\left(5.0 \mathrm{mg} \mathrm{kg}^{-1}\right), \mathrm{Fe}\left(80 \mathrm{mg} \mathrm{kg}^{-1}\right), \mathrm{K}\left(6.0 \mathrm{~g} \mathrm{~kg}^{-1}\right)$, $\mathrm{Mg}\left(0.4 \mathrm{~g} \mathrm{~kg}^{-1}\right)$, Mn $\left(7.5 \mathrm{mg} \mathrm{kg}^{-1}\right), \mathrm{P}\left(5.0 \mathrm{~g} \mathrm{~kg}^{-1}\right)$ and $\mathrm{Zn}$ (75.0 $\left.\mathrm{mg} \mathrm{kg}^{-1}\right)$ by AAFCO, and $\mathrm{P}\left(0.6 \mathrm{~g} \mathrm{~kg}^{-1}\right)$ by MAPA. The maximum allowable concentration of $\mathrm{Zn}\left(2000 \mathrm{mg} \mathrm{kg}^{-1}\right)$ and $\mathrm{Ca}\left(2.4 \mathrm{~g} \mathrm{~kg}^{-1}\right)$ were established by AAFCO and MAPA, respectively. For dogs feed, the minimum allowable concentration of $\mathrm{Ca}\left(6.0 \mathrm{~g} \mathrm{~kg}^{-1}\right), \mathrm{Cu}\left(7.3 \mathrm{mg} \mathrm{kg}^{-1}\right)$, Fe $\left(80 \mathrm{mg} \mathrm{kg}^{-1}\right), \mathrm{K}\left(6.0 \mathrm{~g} \mathrm{~kg}^{-1}\right), \mathrm{Mg}\left(0.4 \mathrm{~g} \mathrm{~kg}^{-1}\right), \mathrm{Mn}$ $\left(5.0 \mathrm{mg} \mathrm{kg}^{-1}\right), \mathrm{P}\left(5.0 \mathrm{~g} \mathrm{~kg}^{-1}\right)$ and $\mathrm{Zn}\left(120 \mathrm{mg} \mathrm{kg}^{-1}\right)$ by AAFCO, and P $\left(0.6 \mathrm{~g} \mathrm{~kg}^{-1}\right)$ by MAPA are legislated. However, the maximum allowable concentrations were instituted for $\mathrm{Ca}\left(25.0 \mathrm{~g} \mathrm{~kg}^{-1}\right), \mathrm{Cu}\left(250 \mathrm{mg} \mathrm{kg}^{-1}\right), \mathrm{Fe}$ (3000 mg kg-1), $\mathrm{Mg}\left(3.0 \mathrm{~g} \mathrm{~kg}^{-1}\right), \mathrm{P}\left(16.0 \mathrm{~g} \mathrm{~kg}^{-1}\right)$ and $\mathrm{Zn}$ (1000 $\left.\mathrm{m} \mathrm{kg} \mathrm{k}^{-1}\right)$ by AAFCO ${ }^{23}$ and $\mathrm{Ca}\left(2.4 \mathrm{~g} \mathrm{~kg}^{-1}\right)$ by MAPA. ${ }^{5}$

For cat feed samples, the concentration of the elements, presented as mean and range, varied as follows: macroelements $\mathrm{Ca}$ (mean: $1.7 \mathrm{~g} \mathrm{~kg}^{-1}$, from 0.34 up to $2.80 \mathrm{~g} \mathrm{~kg}^{-1}$ ), $\mathrm{K}$ (mean: $0.88 \mathrm{~g} \mathrm{~kg}^{-1}$, from 0.51 up to $1.20 \mathrm{~g} \mathrm{~kg}^{-1}$ ), $\mathrm{Mg}$ (mean: $0.17 \mathrm{~g} \mathrm{~kg}^{-1}$, from 0.079 up to $0.34 \mathrm{~g} \mathrm{~kg}^{-1}$ ), $\mathrm{P}$ (mean: $1.4 \mathrm{~g} \mathrm{~kg}^{-1}$, from 0.90 up to $1.9 \mathrm{~g} \mathrm{~kg}^{-1}$ ) and $\mathrm{S}$ (mean: $0.34 \mathrm{~g} \mathrm{~kg}^{-1}$, from 0.18 up to $0.49 \mathrm{~g} \mathrm{~kg}^{-1}$ ); microelements and trace elements $\mathrm{Al}$ (mean: $215 \mathrm{mg} \mathrm{kg}^{-1}$, from 26.5 up to $883 \mathrm{mg} \mathrm{kg}^{-1}$ ), Ba (mean: $11.1 \mathrm{mg} \mathrm{kg}^{-1}$, from 2.3 up to $19.7 \mathrm{mg} \mathrm{kg}^{-1}$ ), $\mathrm{Cr}$ (mean: $0.88 \mathrm{mg} \mathrm{kg}^{-1}$, $<0.1$ up to $1.8 \mathrm{mg} \mathrm{kg}^{-1}$ ), $\mathrm{Cu}$ (mean: $15.0 \mathrm{mg} \mathrm{kg}^{-1}$, from 3.7 up to $21.7 \mathrm{mg} \mathrm{kg}^{-1}$ ), $\mathrm{Fe}$ (mean: $272 \mathrm{mg} \mathrm{kg}^{-1}$, from 121 up to $637 \mathrm{mg} \mathrm{kg}^{-1}$ ), $\mathrm{Mn}$ (mean: $37.7 \mathrm{mg} \mathrm{kg}^{-1}$, from 8.0 up to $93.9 \mathrm{mg} \mathrm{kg}^{-1}$ ), $\mathrm{Ni}$ (mean: $0.74 \mathrm{mg} \mathrm{kg}^{-1},<0.56$ up to $1.1 \mathrm{mg} \mathrm{kg}^{-1}$ ), $\mathrm{Sr}$ (mean: $35.3 \mathrm{mg} \mathrm{kg}^{-1}$, from 10.9 
Table 2. Statistical summary for elemental concentrations in dry feed for dogs and cats

\begin{tabular}{|c|c|c|c|c|c|c|c|c|c|c|}
\hline \multirow{2}{*}{ Parameter } & \multicolumn{2}{|c|}{ Minimum } & \multicolumn{2}{|c|}{ Maximum } & \multicolumn{2}{|c|}{ Average } & \multicolumn{2}{|c|}{ Median } & \multicolumn{2}{|c|}{ SD } \\
\hline & Dog & Cat & Dog & Cat & Dog & Cat & Dog & Cat & Dog & Cat \\
\hline Humidity / \% & 6.0 & 7.1 & 10.3 & 15.0 & 8.2 & 9.1 & 8.1 & 9.4 & 1.0 & 2.0 \\
\hline $\left.\mathrm{Al} / \mathrm{mg} \mathrm{kg}^{-1}\right)$ & 40.2 & 26.5 & 2450 & 883 & 550 & 215 & 124 & 126 & 763 & 234 \\
\hline $\mathrm{Ba} /\left(\mathrm{mg} \mathrm{kg}^{-1}\right)$ & 4.7 & 2.3 & 18.4 & 19.7 & 13.6 & 11.1 & 14.9 & 11.5 & 4.0 & 5.0 \\
\hline $\mathrm{Ca} /\left(\mathrm{g} \mathrm{kg}^{-1}\right)$ & 1.0 & 0.34 & 3.4 & 2.8 & 2.1 & 1.7 & 2.0 & 1.7 & 1.0 & 0.66 \\
\hline $\mathrm{Cr} /\left(\mathrm{mg} \mathrm{kg}^{-1}\right)$ & \multicolumn{2}{|c|}{$<0.1$} & 1.2 & 1.8 & 0.54 & 0.88 & 0.62 & 0.71 & 0.30 & 0.42 \\
\hline $\mathrm{Cu} /\left(\mathrm{mg} \mathrm{kg}^{-1}\right)$ & 3.8 & 3.7 & 33.1 & 21.7 & 14.2 & 15.0 & 18.1 & 16.5 & 7.0 & 6.0 \\
\hline $\mathrm{Fe} /\left(\mathrm{mg} \mathrm{kg}^{-1}\right)$ & 129 & 121 & 366 & 637 & 230 & 272 & 250 & 259 & 66 & 123 \\
\hline $\mathrm{K} /\left(\mathrm{g} \mathrm{kg}^{-1}\right)$ & 0.54 & 0.51 & 1.1 & 1.2 & 0.84 & 0.88 & 0.94 & 0.91 & 0.10 & 0.18 \\
\hline $\mathrm{Mg} /\left(\mathrm{g} \mathrm{kg}^{-1}\right)$ & 0.060 & 0.079 & 0.42 & 0.34 & 0.17 & 0.17 & 0.22 & 0.16 & 0.10 & 0.067 \\
\hline $\mathrm{Mn} /\left(\mathrm{mg} \mathrm{kg}^{-1}\right)$ & 4.5 & 8.0 & 94.9 & 93.9 & 37.0 & 37.7 & 57.9 & 31.9 & 26.0 & 25.0 \\
\hline $\mathrm{Ni} /\left(\mathrm{mg} \mathrm{kg}^{-1}\right)$ & \multicolumn{2}{|c|}{$<0.56$} & 0.88 & 1.1 & 0.69 & 0.74 & $<0.56$ & 0.60 & 0.10 & 0.18 \\
\hline $\mathrm{P} /\left(\mathrm{g} \mathrm{kg}^{-1}\right)$ & 0.92 & 0.90 & 2.4 & 1.9 & 1.4 & 1.4 & 1.2 & 1.3 & 0.40 & 0.29 \\
\hline $\mathrm{S} /\left(\mathrm{g} \mathrm{kg}^{-1}\right)$ & 0.13 & 0.18 & 0.41 & 0.49 & 0.25 & 0.34 & 0.22 & 0.35 & 0.10 & 0.08 \\
\hline $\mathrm{Sr} /\left(\mathrm{mg} \mathrm{kg}^{-1}\right)$ & 26.3 & 10.9 & 101 & 59.5 & 42.3 & 35.3 & 34.7 & 38.1 & 17.0 & 12.0 \\
\hline $\mathrm{V} /\left(\mathrm{mg} \mathrm{kg}^{-1}\right)$ & \multicolumn{2}{|c|}{$<0.21$} & 0.87 & 1.2 & 0.40 & 0.49 & 0.32 & 0.37 & 0.10 & 0.26 \\
\hline $\mathrm{Zn} /\left(\mathrm{mg} \mathrm{kg}^{-1}\right)$ & 38.1 & 40.7 & 378 & 404 & 200 & 155 & 187 & 154 & 114 & 94 \\
\hline
\end{tabular}

SD: standard deviation.

up to $59.5 \mathrm{mg} \mathrm{kg}^{-1}$ ), $\mathrm{V}$ (mean: $0.49 \mathrm{mg} \mathrm{kg}^{-1},<0.21$ up to $1.2 \mathrm{mg} \mathrm{kg}^{-1}$ ) and $\mathrm{Zn}$ (mean: $155 \mathrm{mg} \mathrm{kg}^{-1}$, from 40.7 up to $404 \mathrm{mg} \mathrm{kg}^{-1}$ ).

The concentration in dog feed samples presented as mean and range were: $\mathrm{Ca}$ (mean: $2.1 \mathrm{~g} \mathrm{~kg}^{-1}$, from 1.0 up to $3.4 \mathrm{~g} \mathrm{~kg}^{-1}$ ), $\mathrm{K}$ (mean: $0.84 \mathrm{~g} \mathrm{~kg}^{-1}$, from 0.54 up to $1.1 \mathrm{~g} \mathrm{~kg}^{-1}$ ), $\mathrm{Mg}$ (mean: $0.17 \mathrm{~g} \mathrm{~kg}^{-1}$, from 0.060 up to $0.42 \mathrm{~g} \mathrm{~kg}^{-1}$ ), $\mathrm{P}$ (mean: $1.4 \mathrm{~g} \mathrm{~kg}^{-1}$, from 0.92 up to $2.4 \mathrm{~g} \mathrm{~kg}^{-1}$ ), S (mean: $0.25 \mathrm{~g} \mathrm{~kg}^{-1}$, from 0.13 up to $0.41 \mathrm{~g} \mathrm{~kg}^{-1}$ ), $\mathrm{Al}$ (mean: $550 \mathrm{mg} \mathrm{kg}^{-1}$, from 40.2 up to $2450 \mathrm{mg} \mathrm{kg}^{-1}$ ), Ba (mean: $13.6 \mathrm{mg} \mathrm{kg}^{-1}$, from 4.7 up to $18.4 \mathrm{mg} \mathrm{kg}^{-1}$ ), $\mathrm{Cr}$ (mean: $0.54 \mathrm{mg} \mathrm{kg}^{-1}$, $<0.1$ up to $1.2 \mathrm{mg} \mathrm{kg}^{-1}$ ), $\mathrm{Cu}$ (mean: $14.2 \mathrm{mg} \mathrm{kg}^{-1}$, from 3.8 up to $33.1 \mathrm{mg} \mathrm{kg}^{-1}$ ), $\mathrm{Fe}$ (mean: $230 \mathrm{mg} \mathrm{kg}^{-1}$, from 129 up to $366 \mathrm{mg} \mathrm{kg}^{-1}$ ), Mn (mean: $37.0 \mathrm{mg} \mathrm{kg}^{-1}$, from 4.5 up to $94.9 \mathrm{mg} \mathrm{kg}^{-1}$ ), $\mathrm{Ni}$ (mean: $0.69 \mathrm{mg} \mathrm{kg}^{-1},<0.56$ up to $0.88 \mathrm{mg} \mathrm{kg}^{-1}$ ), $\mathrm{Sr}$ (mean: $42.3 \mathrm{mg} \mathrm{kg}^{-1}$, from 26.3 up to $101 \mathrm{mg} \mathrm{kg}^{-1}$ ), $\mathrm{V}$ (mean: $0.40 \mathrm{mg} \mathrm{kg}^{-1},<0.21$ up to $0.87 \mathrm{mg} \mathrm{kg}^{-1}$ ) and $\mathrm{Zn}$ (mean: $200 \mathrm{mg} \mathrm{kg}^{-1}$, from $38.1 \mathrm{up}$ to $378 \mathrm{mg} \mathrm{kg}^{-1}$ ).

The humidity content of the samples ranged between 6.0 and $10.3 \%$, with an average of $8.2 \%$ for dog feeds, and between 7.1 and $15.0 \%$, with an average of $9.1 \%$ for the cat feeds. According to MAPA, humidity should be below $12 \% .{ }^{5}$ However, in three different feeds for cats (F2, F14, and F15), the content exceeded the regulatory agency standards.

Macroelements, such as $\mathrm{Ca}$ and $\mathrm{P}$, presented the highest concentrations, with average values between 2.1 and
$1.4 \mathrm{~g} \mathrm{~kg}^{-1}$ for dog feeds and between 1.7 and $1.4 \mathrm{~g} \mathrm{~kg}^{-1}$ for cat feeds, respectively. Among the microelements and trace elements, the concentrations of $\mathrm{Al}, \mathrm{Fe}$, and $\mathrm{Zn}$ with mean values of 550,230 and $200 \mathrm{mg} \mathrm{kg}^{-1}$ for dog feeds and 215,272 and $155 \mathrm{mg} \mathrm{kg}^{-1}$ for cat feeds, respectively, were considerable.

The elements, $\mathrm{Al}, \mathrm{Ba}, \mathrm{Cr}, \mathrm{Ni}, \mathrm{S}, \mathrm{Sr}$ and $\mathrm{V}$ are not included in the legislation on the feed composition for dogs and cats. ${ }^{9}$ However, sulfur as sulfides and sulfates are important for blood clotting, and their absence can cause joint pain, as well as mental and physical weakness. ${ }^{24}$ The element $\mathrm{Sr}$ can be very toxic in high concentrations and although it can act in a manner similar to Ca metabolism, it should not replace it. The presence of Ba salts in the diet can raise blood pressure and cause kidney and heart failure, ${ }^{25}$ while $\mathrm{Al}$ has been related to bone diseases and may accumulate in the brain, causing neurological dysfunction. ${ }^{23}$

Similar values for $\mathrm{Cu}, \mathrm{Fe}$ and $\mathrm{Mn}$ were found in a study for pet food diets in Turkey, using flame atomic absorption spectrometry. ${ }^{9}$ In another work, the mineral composition of dog feeds commercialized in Brazil and determined by neutron activation analysis, showed that $\mathrm{Fe}$ and $\mathrm{K}$ concentrations were in accordance with AAFCO, while the concentrations of $\mathrm{Ca}$ and $\mathrm{Zn}$ were below and above the set levels, respectively. ${ }^{3}$ In contrast, reflectance infrared spectrometry was used to study dog feeds marketed in Chile, and it was reported mean values for $\mathrm{Ca}, \mathrm{K}$, $\mathrm{Mg}$ and $\mathrm{P}$ of $16.7,10.5,6.1$ and $1.8 \mathrm{~g} \mathrm{~kg}^{-1}$, respectively, 
which were in accordance with AAFCO, except for Mg. ${ }^{1}$ Other minerals were also determined, including $\mathrm{Fe}$ (353.8 $\left.\mathrm{mg} \mathrm{kg}^{-1}\right), \mathrm{Cu}\left(29.5 \mathrm{mg} \mathrm{kg}^{-1}\right), \mathrm{Mn}\left(66.6 \mathrm{mg} \mathrm{kg}^{-1}\right)$ and $\mathrm{Zn}\left(180.2 \mathrm{mg} \mathrm{kg}^{-1}\right)$, that were in agreement with the AAFCO and the values found in this study. ${ }^{1}$

In a study carried out in the United Kingdom (UK), the concentrations found for macroelements $\mathrm{Ca}, \mathrm{P}, \mathrm{S}$, $\mathrm{Mg}$ and $\mathrm{K}$ were higher than those found in this work, with maximum of 18 and $32 \%$ for cat and dog feeds, respectively. Regarding trace elements as $\mathrm{Zn}, \mathrm{Mn}$ and $\mathrm{Sr}$, the concentrations reported by Davies et al. ${ }^{26}$ were lower than the values found in this study, with maximum percentages of 0.1 and $0.7 \%$ for cat and dog feeds, respectively.

\section{Analysis of feed through the regulatory agencies}

For $\mathrm{Ca}, \mathrm{Cu}, \mathrm{Fe}, \mathrm{K}, \mathrm{Mg}, \mathrm{Mn}, \mathrm{P}$ and $\mathrm{Zn}$, the concentrations found can be compared to values required by regulatory agencies. The values, according to Brazilian (MAPA), ${ }^{5}$ and American (AAFCO) $)^{23}$ legislations, are shown in Figures S1 to $\mathrm{S} 8$ (SI section).

The Ca concentrations (Figure S1) show that the samples F3, F4.1, F5.1 and F8 for dog feeds, and F3.1 and F3.2 for cat feeds, had concentrations above the maximum permitted by the Brazilian law, which is $2.4 \mathrm{~g} \mathrm{~kg}^{-1}{ }^{-5} \mathrm{In}$ dog and cat feeds, Ca concentrations ranged from 1.0 to 3.4 and 0.34 to $2.8 \mathrm{~g} \mathrm{~kg}^{-1}$, respectively.

According to the AAFCO, the concentration of $\mathrm{Ca}$ in dry dog and cat feeds must be at least $6.0 \mathrm{~g} \mathrm{~kg}^{-1}$. Thus, all analyzed samples were outside the parameters established by this agency. ${ }^{23}$

For $\mathrm{Cu}$, the AAFCO requires a minimum and maximum concentration of 7.3 and $250 \mathrm{mg} \mathrm{kg}^{-1},{ }^{23}$ respectively, in dog feeds and a minimum of $5.0 \mathrm{mg} \mathrm{kg}^{-1}$ in cat feeds. Figure S2 shows that F6, F4.2, F4.3 and F9 dog feed samples and $\mathrm{F} 9$ cat feed sample had the minimal concentration established by the AAFCO ${ }^{23}$ The concentrations of $\mathrm{Cu}$ in dog and cat feeds, respectively, ranged from 3.8 to 33.1 and 3.7 to $21.7 \mathrm{mg} \mathrm{kg}^{-1}$. Brazil has no legislation for $\mathrm{Cu}$ concentration. $^{5}$

For $\mathrm{Fe}$ there is no limit of concentration established by the Brazilian law. ${ }^{5}$ However, when comparing with AAFCO limits, all samples presented the minimum $80 \mathrm{mg} \mathrm{kg}^{-1} \mathrm{Fe}$ specified in the legislation (Figure S3) ${ }^{23}$ Concentrations of $\mathrm{Fe}$ in dog and cat feeds, respectively, ranged from 129 to 366 and 121 to $637 \mathrm{mg} \mathrm{kg}^{-1}$. It is noteworthy that no sample of $\operatorname{dog}$ feed exceeded the maximum established limit of $3000 \mathrm{mg} \mathrm{kg}^{-1}$. Maximum value is not provided for cat feeds.

Regarding $\mathrm{K}$ and $\mathrm{Mg}$ concentrations, no samples complied with the minimum value specified by the AAFCO, $6.0 \mathrm{~g} \mathrm{~kg}^{-1}$ for $\mathrm{K}$ and $0.4 \mathrm{~g} \mathrm{~kg}^{-1}$ for $\mathrm{Mg},{ }^{23}$ except for the $\mathrm{F} 6$ sample in dog feeds, as shown in Figures S4 and S5. The maximum permissible $\mathrm{Mg}$ concentration set by the AAFCO is $3.0 \mathrm{~g} \mathrm{~kg}^{-1} \cdot{ }^{23}$

The concentrations of $\mathrm{K}$ and $\mathrm{Mg}$ in the dog feeds ranged from 0.54 to 1.1 and from 0.060 to $0.42 \mathrm{~g} \mathrm{~kg}^{-1}$, respectively. In cat feeds, they were from 0.51 to $1.2 \mathrm{~g} \mathrm{~kg}^{-1}$ for $\mathrm{K}$ and from 0.079 to $0.34 \mathrm{~g} \mathrm{~kg}^{-1}$ for $\mathrm{Mg}$.

Concentrations of $\mathrm{Mn}$, found in samples of dog and cat feeds (Figure S6), complied with the values established by the AAFCO, with a minimum of $5.0 \mathrm{mg} \mathrm{kg}^{-1}$ for $\mathrm{dog}$ feed and $7.5 \mathrm{mg} \mathrm{kg}^{-1}$ for cat feed, except for the F9 dog feed sample. ${ }^{23}$ The concentration of $\mathrm{Mn}$ in dog feed samples ranged from 4.5 to $94.9 \mathrm{mg} \mathrm{kg}^{-1}$, and in cat feeds from 8.0 to $93.9 \mathrm{mg} \mathrm{kg}^{-1}$.

Concentrations of P, shown in Figure S7, were in agreement with Brazilian requirements (at least $0.6 \mathrm{~g} \mathrm{~kg}^{-1}$ ) in dog and cat feed samples. ${ }^{5}$ The concentrations of $\mathrm{P}$ in the dog feeds ranged from 0.92 to $2.40 \mathrm{~g} \mathrm{~kg}^{-1}$, and in cat feeds from 0.90 to $1.90 \mathrm{~g} \mathrm{~kg}^{-1}$. None of the samples showed the minimal $\mathrm{P}$ concentration set by the AAFCO of $5.0 \mathrm{mg} \mathrm{kg}^{-1} \cdot{ }^{23}$

Figure S8 provides the $\mathrm{Zn}$ concentrations found in the samples. The samples F4.1, F4.2, F4.3, F2, F5, F6, F9 and F10 of dog feeds and F9.1, F9.2, F14 and F16 of cat feeds presented minimal concentrations, below those established by the AAFCO $\left(120 \mathrm{mg} \mathrm{kg}^{-1}\right.$ for dog feed and $75.0 \mathrm{mg} \mathrm{kg}^{-1}$ for cat feed). ${ }^{23}$ The concentrations of $\mathrm{Zn}$ in dog feeds ranged from 38.1 to $378 \mathrm{mg} \mathrm{kg}^{-1}$, and in cat feeds from 40.7 to $404 \mathrm{mg} \mathrm{kg}^{-1}$.

Macroelements $\mathrm{Ca}, \mathrm{K}, \mathrm{Mg}$, and $\mathrm{P}$, are essential for the proper functioning of the body. The absorption of $\mathrm{Ca}$ and $\mathrm{P}$ can be compromised by increasing the availability of minerals in the diet. Besides, the presence of metals, such as $\mathrm{Fe}, \mathrm{Mg}, \mathrm{Ca}$ and $\mathrm{Al}$, may promote the formation of insoluble phosphates hindering the absorption of $\mathrm{P}$, leading to malfunctioning of the body. ${ }^{3,27}$ High concentrations of these metals can also inhibit the absorption of other elements, such as Mn and Zn. Also, the absorption of $\mathrm{Mg}$ can be affected by an increase in $\mathrm{Ca}$ and $\mathrm{P}$ concentrations in feed. The importance of $\mathrm{K}$ is related to its high digestibility coefficient, being responsible for regulating the osmotic pressure and the transmission of nerve impulses. Absorption of Fe in vivo may be influenced by age and the dietary origin, and it decreases in the presence of $\mathrm{Ca} .{ }^{9}$

Studies also reported that the absorption of $\mathrm{Cu}$, which is an essential microelement, can be decreased by $\mathrm{Ca}, \mathrm{Fe}, \mathrm{Cd}$, and $\mathrm{Zn}$, which compete for transport with the same enzyme. In turn, $\mathrm{Zn}$, which is important in the development of the skeleton and sexual organs, is low and can be decreased when the diet contains high $\mathrm{P}, \mathrm{Ca}$ and $\mathrm{Cu}$ concentrations. ${ }^{3,9}$ 
It was discussed the symptoms of excess Mn, which can cause chronic neurotoxicity, with symptoms that resemble Parkinson's disease, such as tremors and difficulty in movement. ${ }^{9}$

\section{Pattern recognition}

The concentrations of the 15 elements determined in 41 samples of cat (17 samples) and dog feeds were further analyzed by pattern recognition techniques using the unsupervised method. This method examines the similarities and differences between samples or variables from a set of multivariate data analysis, such as PCA and HCA. ${ }^{28-30}$ Hence, the clustering of the samples using the concentrations of 15 elements ( $\mathrm{Al}, \mathrm{Ba}, \mathrm{Ca}, \mathrm{Cr}, \mathrm{Cu}, \mathrm{Fe}, \mathrm{K}$, $\mathrm{Mg}, \mathrm{Mn}, \mathrm{Ni}, \mathrm{P}, \mathrm{S}, \mathrm{Sr}, \mathrm{V}$ and $\mathrm{Zn}$ ), the flavors of the products and the product brands as the variables were evaluated. The data were pre-processed using auto-scaling for dog and cat feeds, ${ }^{28}$ respectively, and the first three principal components (PCs) were observed in both instances. For chemometric analysis was employed Statistica version 6.0 software ${ }^{31}$ (StatSoft, Tulsa, USA).

Concerning the dog and cat feeds, the loadings of the original variables in the first three PCs and variations explained in each component are given in Table 3 . The first three PCs represented $65.4 \%$ of the total data variability, which was sufficient to describe a system consisting of
24 dog feed samples. PC1 accounted for $30.5 \%$ of the data variability. The dominant variables of this $\mathrm{PC}$ were the concentrations of $\mathrm{Ca}, \mathrm{Mg}$ and $\mathrm{P}$, with positive loadings, followed by the concentrations of $\mathrm{Al}$ and $\mathrm{Cu}$, with negative loadings. PC2 explained $23.3 \%$ of the total variability. The concentrations of $\mathrm{Fe}, \mathrm{K}$, and $\mathrm{S}$, with negative loadings, were the most dominant variables, establishing a probable correlation with $\mathrm{Mn}$ and $\mathrm{Zn}$ concentrations. Finally, PC3 explained $11.5 \%$ of the total variability and described the concentrations of $\mathrm{Al}, \mathrm{Cr}$, and $\mathrm{V}$ of dog feed samples.

Figure 1 shows the projection of the first three PCs, for dog feed, that described $65.4 \%$ of the total variance. There was a tendency to form three sets of points but not a complete separation between the samples. The flavor parameter (Figure 1a), had a set with high scores in PC3, which were negatively influenced by the $\mathrm{Al}, \mathrm{Cr}$, and $\mathrm{V}$ concentrations, corresponding to a cluster of the flavors: meat, vegetables and mixtures (mix), according to the packages. The values corresponding to a high PC2 were negatively influenced by the $\mathrm{Fe}, \mathrm{K}$, and $\mathrm{S}$ concentrations by grouping the meat flavor with the addition of vegetables, cereals, and chicken or bone flavors. The values corresponding to a high PC1 formed a specific group of meat flavored feed, which had positive loadings for $\mathrm{Ca}, \mathrm{Mg}$ and $\mathrm{P}$ and negative loadings for $\mathrm{Al}, \mathrm{Cu}$, and $\mathrm{S}$. However, $\mathrm{Ca}$ and $\mathrm{Mg}$ presented the most influence, with higher concentrations of these elements located at the highest points of the set.

Table 3. Loadings values for the first three PCs for dog and cat feed samples

\begin{tabular}{|c|c|c|c|c|c|c|}
\hline \multirow{2}{*}{ Variable } & \multicolumn{2}{|c|}{$\mathrm{PC} 1$} & \multicolumn{2}{|c|}{$\mathrm{PC} 2$} & \multicolumn{2}{|c|}{$\mathrm{PC} 3$} \\
\hline & Dog & Cat & Dog & Cat & Dog & Cat \\
\hline $\mathrm{Al}$ & -0.661 & 0.769 & -0.175 & 0.003 & -0.522 & 0.237 \\
\hline $\mathrm{Ba}$ & 0.473 & 0.816 & 0.220 & 0.376 & -0.362 & 0.082 \\
\hline $\mathrm{Ca}$ & 0.817 & 0.796 & -0.034 & -0.205 & -0.263 & -0.300 \\
\hline $\mathrm{Cr}$ & 0.471 & 0.302 & 0.184 & 0.255 & -0.500 & -0.618 \\
\hline $\mathrm{Cu}$ & -0.811 & -0.057 & -0.270 & -0.792 & -0.096 & 0.275 \\
\hline $\mathrm{Fe}$ & 0.393 & 0.774 & -0.810 & -0.365 & -0.150 & 0.299 \\
\hline K & -0.135 & -0.273 & -0.745 & 0.312 & 0.302 & -0.360 \\
\hline $\mathrm{Mg}$ & 0.698 & 0.629 & -0.194 & 0.443 & 0.252 & 0.518 \\
\hline $\mathrm{Mn}$ & 0.475 & 0.041 & -0.556 & -0.178 & 0.470 & 0.769 \\
\hline $\mathrm{Ni}$ & 0.523 & 0.677 & -0.472 & -0.264 & 0.318 & -0.002 \\
\hline $\mathrm{P}$ & 0.694 & 0.482 & -0.456 & -0.246 & -0.329 & -0.465 \\
\hline S & -0.555 & -0.176 & -0.731 & -0.764 & -0.106 & -0.348 \\
\hline $\mathrm{Sr}$ & 0.324 & 0.564 & 0.288 & -0.248 & 0.192 & -0.417 \\
\hline V & 0.302 & 0.620 & -0.487 & -0.213 & -0.607 & -0.100 \\
\hline $\mathrm{Zn}$ & -0.483 & -0.304 & -0.684 & -0.862 & -0.045 & 0.110 \\
\hline Total variance / \% & 30.6 & 30.5 & 23.3 & 19.3 & 11.5 & 14.8 \\
\hline Accumulated variance / $\%$ & 30.6 & 30.5 & 53.9 & 49.8 & 65.4 & 64.6 \\
\hline
\end{tabular}


- Chicken and bones with meat or corn or milk Meat and plant
Meat Mixture
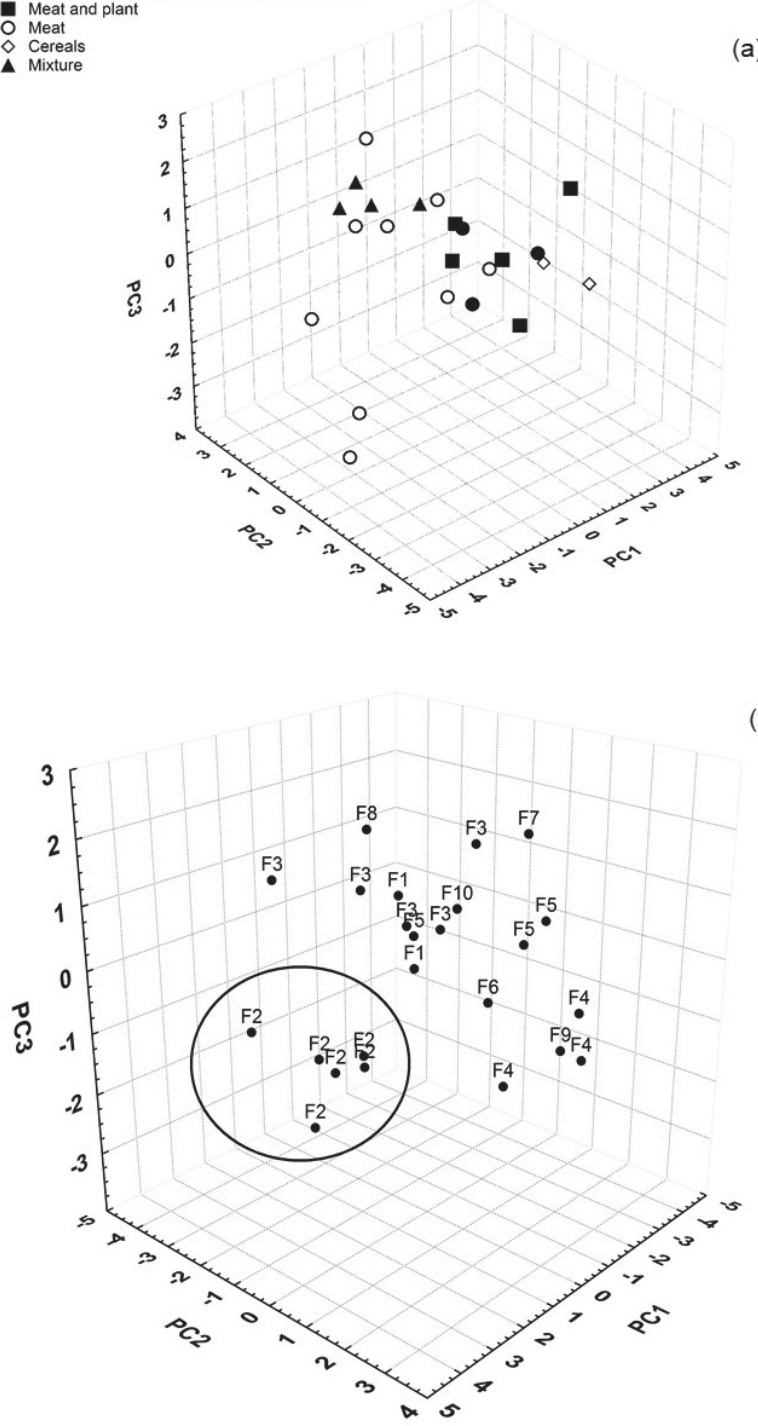

(b)

Figure 1. Score chart for $\mathrm{PC} 1 \times \mathrm{PC} 2 \times \mathrm{PC} 3$ projection, considering the parameters: (a) flavor and (b) manufacturer of the dog feeds.

Figure $1 \mathrm{~b}$ shows the projection of the first PC, considering the brand. The feeds brand clustered F2 dog feeds, and this group correlated to the concentrations of $\mathrm{Al}, \mathrm{Cu}$, and $\mathrm{S}$, which had a negative influence on PC1. For the other brands, no correlations were observed, that is, a uniformity of mineral composition between them, noting the proximity of the samples of each brand.

For cat feeds, the first three PCs contributed 64.6\% of the total data variability, as shown in Table 2 and it was sufficient to describe the system comprising 17 cat feed samples. PC1 represented $30.5 \%$ of the total data variability, which was most influenced by the variables $\mathrm{Al}$, $\mathrm{Ba}, \mathrm{Ca}, \mathrm{Fe}, \mathrm{Mg}, \mathrm{Ni}$ and $\mathrm{V}$ due to their high loadings. PC2 presented negative loadings for $\mathrm{Cu}$, and $\mathrm{Zn}$, which were the main elements responsible for the data variability. PC3 was mainly influenced by the concentrations of Mn and
$\mathrm{Cr}$, with high loadings, but with opposite signs. The Mn concentration loading had a positive influence, whereas, the $\mathrm{Cr}$ concentration had a negative loading, indicating that, as the concentration of $\mathrm{Mn}$ in the sample increases, the concentration of $\mathrm{Cr}$ decreases. The scores graph of the cat feed samples for the first three PCs are shown in Figure 2.

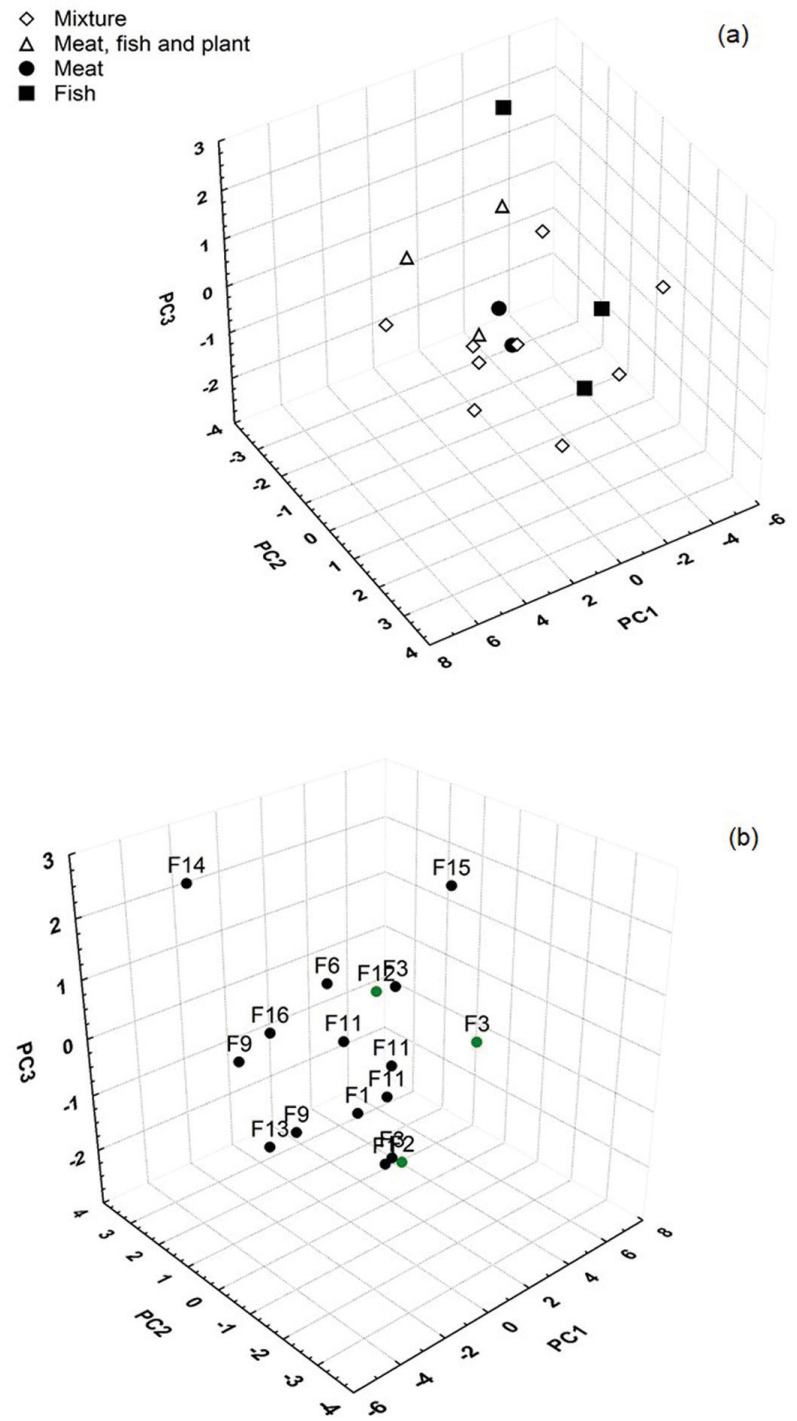

Figure 2. Scores graphs of cat feed samples for the first three PCs, considering: (a) flavors and (b) manufacturers.

There was no trend in the formation of groups, for both the description of the flavors (Figure 2a) and the identification of the brands (Figure 2b), suggesting that these diets are essentially made from similar ingredients. Hence, there was no standard for the different flavors and brands analyzed in this work by multivariate analysis of the data on the mineral composition of the samples.

The auto-scaled data of cat and dog feed samples were evaluated by HCA, according to the specification of the product brand. Ward's linkage method was used to evaluate 
the distance between the small clusters, and the Euclidean distance method to calculate the interpoint distances. For a distance equivalent to a $72 \%$ dissimilarity between samples, two groups were observed (Figure 3). The first set was associated with the F2 brand and the second set comprised the other brands (F1 to F10).
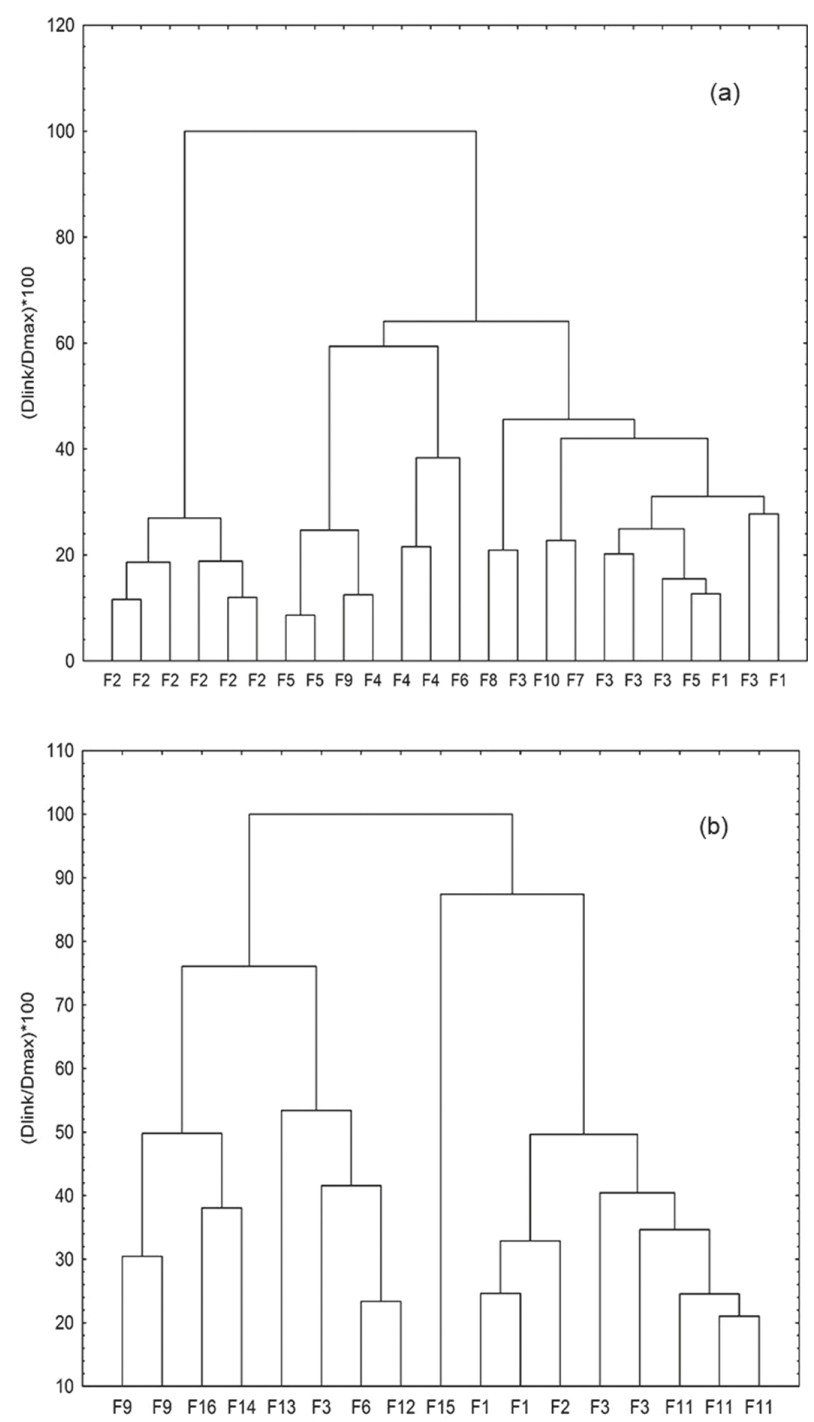

Figure 3. Dendrogram of dry (a) dog feed and (b) cat feed samples according to feed brands.

The separation of the dog feeds identified by F2, as shown in Figure 3a, was based mainly on the concentrations of $\mathrm{Al}$ and $\mathrm{Cu}$, as shown in PCA. However, it is reasonable to conclude that, there was no trend in the differentiation of the other brands so sharp (F3, F1, F4, F5), since the feed is produced from various ingredients, and often, not all the ingredients are included on the packaging, so it is not possible to differentiate exactly the chemical composition.

For cat feed samples, no trend in specific grouping was observed (Figure 3b), due to the lack of specification of the ingredients used by brands in the production of cat feeds, only the clustering between the samples of the same brands (F9, F1, F3 and F11).

Figure $4 \mathrm{a}$ shows the dendrogram for dog feeds, according to the flavors. Among the flavors for these feed samples, four groups were observed. The first consisted of the samples having meat, cereals, chicken and plant flavors. The second group comprised only the meat flavored samples. The predominance of blends, which was listed on the packaging composition, was the main source of clustering the samples in the third group.
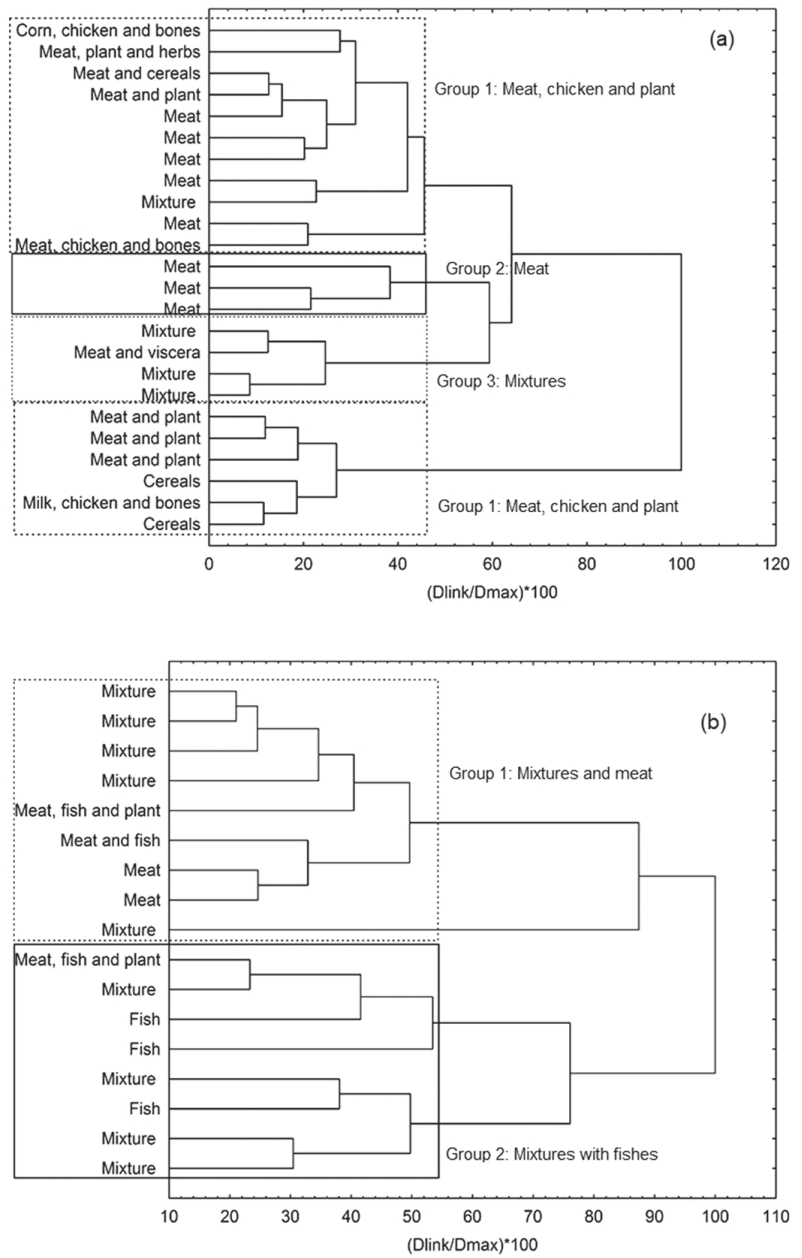

Figure 4. Dendrogram samples according to flavor of (a) dry dog feed and (b) dry cat feed.

In the dendrogram of the investigation of the flavor of the cat feed samples (Figure 4b), two groups were formed with $45 \%$ similarity between the samples. One group comprised the samples with mixtures and meat flavors, whilst the second group of samples comprised mixtures and fish flavors. It is probable that any ingredient in the flavor mixtures has meat or fish in its composition, causing the samples of meat or fish to group only with their mixture. 
Many brands report on their packaging that they are blends, however, with little description of the ingredients employed in manufacturing.

\section{Conclusions}

The concentrations of chemical elements in dry dog and cat feeds were compared with the limit values set by regulatory agencies (MAPA/Brazil and AAFCO/USA). Obtained values for $\mathrm{P}$ consistently complied with the Brazilian legislation (MAPA). The concentrations of $\mathrm{Cu}$, $\mathrm{K}$ and $\mathrm{Mg}$ were below the values permitted for cat and dog feeds according to AAFCO. Only the concentrations of Mn and $\mathrm{Zn}$ in dog feeds complied with the American legislation. The maximum values of $\mathrm{Al}, \mathrm{Cu}$, and $\mathrm{Sr}$ were observed in dog feeds and the highest concentrations of $\mathrm{Fe}$ and $\mathrm{Zn}$ occurred in the cat feeds. The concentrations of $\mathrm{Ba}, \mathrm{Ca}, \mathrm{Cr}$, $\mathrm{Mg}, \mathrm{Mn}, \mathrm{Ni}, \mathrm{P}, \mathrm{S}$ and $\mathrm{V}$ values were similar in both cat and dog feeds. Concentrations of $\mathrm{Cd}\left(<0.12 \mathrm{mg} \mathrm{kg}^{-1}\right)$ was also determined, but the obtained values for this element were below the LOQ of the analytical method applied.

From the multivariate data analysis using PCA and HCA, it can be concluded that the feeds for dogs and cats show uniformity as there was no trend to form separate groups for a possible classification, considering the variables analyzed. The exception was the F2 brand, which was separated from the cluster due to the predominance of $\mathrm{Al}$ and $\mathrm{Cu}$ concentrations in the feed samples intended for dogs.

\section{Supplementary Information}

Supplementary data are available free of charge at http://jbcs.sbq.org.br as PDF file.

\section{Acknowledgments}

This study was financially supported by fellowships from Conselho Nacional de Desenvolvimento Científico e Tecnológico (CNPq, Brazil) and Fundação de Amparo à Pesquisa do Estado da Bahia (FAPESB, Brazil). The infrastructure was provided by Instituto Tecnológico e de Pesquisa do Estado de Sergipe (ITPS, Brazil) and Laboratório de Química Analítica Ambiental (LQA)-UFS (Brazil).

\section{References}

1. Alomar, D.; Hodgkinson, S.; Abarzúa, D.; Fuchslocher, R.; Alvarado, C.; Rosales, E.; J. Anim. Physiol. Anim. Nutr. 2006, $90,223$.
2. da Costa, S. S. L.; Pereira, A. C. L.; Passos, E. A.; Alves, J. P. H.; Garcia, C. A. B.; Araujo, R. G. O.; Talanta 2013, 108, 157.

3. Elias, C.; Fernandes, E. A. N.; Bacchi, M. A.; J. Radioanal. Nucl. Chem. 2012, 291, 245.

4. França, J.; Saad, F. M. O. B.; Saad, C. E. P.; Silva, R. C.; Reis J. S.; Rev. Bras. Zootec. 2011, 40, 222.

5. Ministério da Agricultura, Pecuária e Abastecimento (MAPA); Instrução Normativa No. 9, de 9 de julho de 2003; MAPA: Brasília, 2003.

6. Zicker, S. C.; Top. Companion Anim. Med. 2008, 23, 121.

7. Carciofi, A. C.; Rev. Bras. Zootec. 2008, 37, 28.

8. Cavalari, A. P. M.; Donzele, J. L.; Viana, J. A. M.; Abreu, L. T.; Oliveira, A. L. S.; Freitas, L. S.; Pereira, A. A.; Carciofi, A. C.; Rev. Bras. Zootec. 2006, 35, 1985.

9. Duran, A.; Tuzen, M.; Soylak, M.; Food Chem. Toxicol. 2010, 48, 2833.

10. França, J.; Saad, F. M. O. B.; Silva Jr., J. W.; Numajiri, L. N.; Pinto, A. B.; Chizzotti, A. F.; Rev. Bras. Saude Prod. Anim. 2008, 9, 449.

11. Rocha, M. A.; Rev. Bras. Zootec. 2008, 37, 42.

12. Santos, J. P. F.; Saad, F. M. O. B.; Roque, N. C.; Aquino, A. A.; Pires, C. P.; Geraldi, L. F.; Arq. Bras. Med. Vet. Zootec. 2011, 63, 687.

13. Thompson, A.; Top. Companion Anim. Med. 2008, 23, 127.

14. Ávila, D. V. L.; Souza, S. O.; Costa, S. S. L.; Araujo, R. G. O.; Garcia, C. A. B.; Alves, J. P. H.; Passos, E. A.; J. AOAC Int. 2016, 99, 1572.

15. Perring, L.; Nicolas, M.; Andrey, D.; Rime, C. F.; Richoz-Payot, J.; Dubascoux, S.; Poitevin, E.; Food Anal. Methods 2016, 10, 1469.

16. Tormen, L.; Torres, D. P.; Dittert, I. M.; Araújo, R. G. O.; Frescura, V. L. A.; Curtius, A. J.; J. Food Compos. Anal. 2011, $24,95$.

17. Santos, I. F.; Barbosa, A. M. P.; Lima, J. S.; Santos, D. C.; Matos, G. D.; Microchem. J. 2013, 110, 439.

18. Santos, A. M. P.; Lima, J. S.; Anunciação, D. S.; Souza, A. S.; Santos, D. C. M. B.; Matos, G. D.; Food Anal. Methods 2013, 6,745 .

19. Anunciação, D. S.; Leao, D. J.; Jesus, R. M.; Ferreira, S. L. C.; Food Anal. Methods 2011, 4, 286.

20. Lima, D. C.; Santos, A. M. P.; Araujo, R. G. O.; Scarminio, I. S.; Bruns, R. E.; Ferreira, S. L. C.; Microchem. J. 2010, 95, 222.

21. Fadigas, J. C.; Santos, A. M. P.; Jesus, R. M.; Lima, D. C.; Fragoso, W. D.; David, J. M.; Ferreira, S. L. C.; Microchem. J. 2010, 96, 352.

22. Patras, A.; Brunton, N. P.; Downey, G.; Rawson, A.; Warriner, K.; Gernigon, G.; J. Food Compos. Anal. 2011, 24, 250.

23. Association of American Feed Control Officials (AAFCO); AAFCO Dog and Cat Food Nutrient Profiles; AAFCO: Champaign, 2014. 
24. Machado, R. M. D.; Toledo, M. C. F.; Vicente, E.; Braz. J. Food Technol. 2006, 9, 265.

25. World Health Organization (WHO); Barium and Barium Compounds, Concise International Chemical Assessment; WHO: Geneva, 2001.

26. Davies, M.; Alborough, R.; Jones, L.; Davis, C.; Williams, C.; Gardner, D. S.; Sci. Rep. 2017, 7, 1.

27. Celik, U.; Oehlenschlager, J.; Food Control 2007, 18, 258.

28. Ferreira, M. M. C.; Morgano, M. A.; Queiroz, S. C. N.; Mantovani, D. M. B.; Food Chem. 2000, 69, 259.
29. Correia, P. R. M.; Ferreira, M. M. C.; Quim. Nova 2007, 30, 481.

30. Wold, S.; Esbensen, K.; Geladi, P.; Chemom. Intell. Lab. Syst. 1987, 2, 37.

31. StatSoft, Inc.; Statistica, version 6.0; StatSoft, Inc., Tulsa, OK, USA, 2001.

Submitted: May 12, 2018

Published online: July 25, 2018 